Available online at www.jmle.org

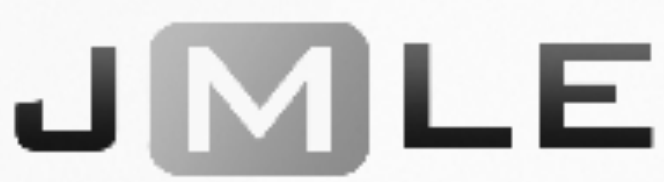

The National Association for Media Literacy Education's

Journal of Media Literacy Education 10 (3), 95 - 112

\title{
How Brazil's Unified University Entrance Exam (ENEM) Impacts Media Literacy Education
}

\author{
Danilo Venticinque \\ Andrew Whitworth \\ University of Manchester, UK
}

\begin{abstract}
This article discusses the outcomes of research into the media literacy aspects of ENEM (Exame Nacional do Ensino Médio), Brazil's unified university entrance exam, which contains a significant number of exam questions based on excerpts from newspaper articles, online news and other media sources. Through content analysis, these questions are classified according to the platform (digital or print) and source (traditional media, niche media and government agencies). The results show a strong prevalence of traditional media, either in print or digital platforms, and a tendency to present the government in a positive light, avoiding issues such as the series of protests that took place in Brazil in 2013 and 2014, as well as the impeachment of the president in 2016. The content analysis is followed by the qualitative study of eleven interviews with high school teachers who prepare students for the exam. Their answers suggest that the exam has a profound influence on their teaching and the media consumption habits of students. Teachers also mention regional bias in the exam and a lack of questions that encourage critical thinking. The conclusion is that though the ENEM exam does engage Brazilian high school students with media content, it addresses media literacy at only a functional level, and centralises authority over the interpretation of this content, rather than encouraging students to develop their own authoritative interpretations.
\end{abstract}

Keywords: ENEM, Media literacy, Brazil

This article discusses the outcomes of research into the media literacy aspects of ENEM (Exame Nacional do Ensino Médio), Brazil's unified university entrance exam. On the surface the exam appears to be a means by which media literacy education, and engagement with news media, can enter the mainstream of a secondary education system in line with ways suggested by Renee Hobbs amongst others (1997, 1998, 2005). The research was undertaken to determine how the structure and content of the exam influences how media literacy is taught in Brazil, and whether the exam allows learners to engage with media content in ways which helps them assert authority over it (Hamelink 1976). 
Created in 1998, Brazil's ENEM (Exame Nacional do Ensino Medio, or National Exam of Secondary Education) was, at first, an exam designed to evaluate the educational system in Brazil, but eventually it replaced traditional university entrance exams. Previously, each Brazilian university would organise and implement its own entrance exam with a syllabus loosely based on guidelines from the Ministry of Education. Such exams, which were content-focused and often required memorisation of facts and figures (INEP, 2007), had been widely criticised by teachers and students.

In contrast, ENEM is built to evaluate not the knowledge of content, but competencies and abilities developed during secondary education. A government document detailing the foundations of ENEM lists 21 such abilities and competencies, which include "confronting diverse interpretations of situations and facts of historicgeographic, technic-scientific, artistic-culture or daily nature, comparing different points of view, identifying assumptions of each interpretation and analysing the validity of arguments," "being able to compare processes of socioeconomic formation, relating to their historic and geographic contexts," and "given a set of pieces of information about a historic/geographic reality, contextualise and order registered events, understanding the importance of social, economic, political and cultural factors" (translated from INEP, 2000).

The competency-based approach adopted by ENEM means that it does not have a content syllabus like traditional university exams. Instead, the content of several different classes in secondary education is brought together in questions that are relevant to students' experience. The focus on "real-life" experiences has been used in promotional material for the exam, with slogans such as "ENEM prepares you for the tests of life""

A strategy frequently used to make the exam content relevant to the students' daily life is to create hypothetical everyday situations in which knowledge of subjects such as Mathematics can be used to solve a problem, such as calculating compound interest in a savings account. In subjects such as History, Literature and Geography, in which direct, concrete problem-solving is not always possible or is not sufficient to cover the entirety of the content, ENEM questions relate subject knowledge to current events. This is usually through the use of excerpts from newspapers and magazines that accompany the question. A news article about the signing of a new trade agreement might contextualise a question about globalisation, or an article on the rise of nationalism in Europe might accompany a question that asks students to define nationalism and its impacts during the twentieth century.

The constant use of references to current events as a way of contextualising subject content in ENEM has a great impact on the way students prepare for the exam (Auxiliadora \& Schmidt, 2015). They are expected not only to know about subjects, but to have a substantial knowledge of current events and to be able to relate what they learn in the classroom with what they see on the news. For example, the 2014 exam included questions about recent changes in Brazilian economic policy, government projects that proposed changes in the National Amnesty Laws implemented after the

\footnotetext{
${ }^{1}$ download.inep.gov.br/download/enem/2005/revista enem 05.pdf (translated from Portuguese by the | authors)
} 
end of the military dictatorship, and the increasing water shortage in southern states, particularly São Paulo.

Each question about a current event in ENEM is accompanied by an excerpt of a news article, taken from a source cited within the question. However, the information presented in the exam is usually not enough for a student to find the appropriate answer. To succeed in ENEM, a wider background knowledge of media and current events is therefore required, something which schools can help students develop (Hipolito \& Silveira 2011). This has had a considerable influence in the curriculum of secondary education in Brazil, since schools are ranked according to their ENEM scores and students understandably seek higher-ranking schools, given the importance of the exam for attaining a place in the top public universities, which are considered the elite institutions in the nation. Although the idea of using the students' average ENEM score as a way of evaluating the schools has been described by literature as illusory and superficial at best (Lopes \& López, 2010, p. 101), and overrated and dangerous at worst (Travitzki, Calero \& Boto, 2014, p. 178), Andrade (2011) points out that directors of low-scoring schools are often questioned by students' parents, who demand an explanation for poor performance and expect the adoption of new strategies to improve the school's rank.

In what has been described as a competition between schools (Santos 2011), there have been a series of curriculum changes by several secondary schools across the country to allow them to teach their classes in a more ENEM-friendly manner. Due to the increasing importance of current events and the media in ENEM, this has made media literacy an unavoidable topic in the curriculum of secondary education in Brazil. Students are expected to learn how to follow the news, compare and contrast the information from different sources and relate what they see in the media with content they study in the classroom.

In a scenario similar to that seen in Turkey (Cakmak \& Tuzel 2015), there have been two main strategies to include media literacy in the curriculum. Some schools have hired journalists and communication graduates to teach "media" or "journalism" classes alongside the usual secondary school subjects, to prepare students for the media-related aspects of ENEM. Others preferred to maintain their current curriculum, but encourage each teacher to discuss in class how current events can be related to their subject - much in the way an ENEM question does (Hipolito \& Silveira, 2011).

Among academics, there is no consensus about which approach should be preferred. The interdisciplinary approach has been praised due to the fact that it does not rely on hiring new staff, which makes it more accessible, and can allow for the use of media content to enhance the teaching of other disciplines (Hobbs 1997). It has also been shown that the inclusion of media literacy into the syllabus of writing classes had a significant positive effect on students' abilities to identify the key ideas in an article (Hobbs \& Frost 2003). However, there have been concerns that the lack of a class exclusively dedicated to media literacy can lead the subject to be marginalised in the curriculum, and that teachers of other subjects might not have received appropriate training to deliver media literacy sessions (Hobbs 1998).

On the surface, the treatment given to current events in ENEM seems to be consistent with the ideas of media literacy education found in the work of Hobbs 
(1997), who raises awareness of the importance of media literacy to prepare students to function as informed citizens in a democracy (p. 175). A key aspect of this approach to media literacy education is that schools should not protect students from mass media or teach them to reject the media's influence. Instead, they should encourage them to engage with the media on their own terms, being able to select information from multiple sources, analyse them, evaluate them and create their own interpretation (Hobbs, 2005). This should be done with no explicit political ideological agenda in mind, except for the "radical enough" agenda of "teaching students to question textual authority and to use reasoning to reach autonomous decisions" (Hobbs, 1998, p. 22).

A more politicised approach to media literacy education can be found in the work of Hamelink who warns against the power of what he calls "institutionalised public media" (1976, p. 120) as an instrument that communicates the interests of the powerful and oppresses the general public, preventing them from creating their own world views. Nam (2010) also argues that media literacy education should be transformative and counter-hegemonic in its essence, attributing to teachers the job of helping students "unearth the hidden politics of the media in relation to social problems" (p.14). The development of critical consciousness (conscientização) would be a step towards liberation (Freire, 1970), making media literacy a first step in a route towards emancipation (Livingstone, 2008). Nam's approach to media literacy education is compatible with the concept of radical information literacy (Whitworth, 2014), which emphasises the need to attend to the political nature of communication, a process in which education is a route to decolonisation, as it contributes to the distribution of authority over media and information, developing in learners the capacity to scrutinise the claims made through various media by dominant and colonising interests in society.

Since the Brazilian high school and prep school curriculum for media literacy, as other subjects (Lopes \& López 2010, Santos 2011), is fundamentally shaped by ENEM, this raises the question of whether a government-led, standardised exam is compatible with the political awareness which is at the heart of critical media literacy education. Does ENEM promote this critical approach, or a more functional one? Are learners being expected to scrutinise and critique media content, or accept its authority? These questions have driven the present study.

\section{METHODS}

The first step in the research process is a content analysis using a dataset comprising all ENEM exam questions from 2009 to 2016. The full exams are publicly available at the INEP website ${ }^{2}$. The units of analysis are questions extracted from the exams. Each exam consists of ten foreign language questions (students choose five questions in either Spanish or English), 175 questions on other subjects, also multiplechoice, and one writing task, for a total of 186 questions per exam. The full data set is formed by 1488 questions from eight exams. From this set, questions were extracted for analysis if they included a reference to a media source and/or discussed news events that took place up to five years before the exam date. A total of 289 (19.4\%) questions

\footnotetext{
${ }^{2}$ http://portal.inep.gov.br/provas-e-gabaritos
} 
fit the criteria: 281 multiple-choice questions and all eight writing tasks. From this point these 289 questions are considered to be the data set.

The questions were categorised according to the media platform they cite (print or digital) and the status of the media outlet (traditional, niche or governmental source). "Traditional" media is defined in this article as outlets that are owned by the four main media groups in Brazil (Grupo Folha, Organizações Globo, Editora Abril, Grupo Estado), and foreign sources of similar status. "Niche" applies to non-governmental publications that are not affiliated with the aforementioned media groups. Government sources include websites with ".gov.br" domains and print campaigns by government organs.

The second step in the research was to investigate how the content and structure of the ENEM exam questions may have affected the way media literacy is taught in Brazil. This was done through a series of interviews with teachers from Brazilian schools who teach current events to ENEM candidates. Twenty-two teachers chosen by purposive sample were contacted for the interview and eleven replied, from a wide range of backgrounds. The least experienced teacher in the sample has been teaching for five years, while the most experienced taught for 34 years. History teachers are a majority (five in total), while the other six are distributed among several subjects. Two of them teach Geography. Arts, English and Mathematics are each represented by one teacher in the sample. One of the teachers is fully dedicated to current events, teaching a Journalism class at a private preparatory school. Note that our sample contained teachers from both the private and public sectors in Brazil, and several participants had taught in both over their careers. Our research did not consider whether there were differences in teachers' opinions and practices depending on the sector they taught in, but this might be a topic for further research.

\section{Content Analysis}

As Figure 1 shows, the number of questions on current events in ENEM was slightly higher in the first three years of the sample (2009-11). 2011 was the year with the highest amount of questions (47 out of 186), while 2015 was the lowest (27).

Mentions of print media sources were a majority in the first three years, but the gap between print and digital platforms kept decreasing until 2012, when digital platforms surpassed print. Figure 2 shows this trend.

However, the shift towards digital platforms did not affect the dominance of traditional media in ENEM. Although the 2009 exam showed a balance between traditional media, niche media and government sources, all exams from 2010 to 2014 extracted more than $50 \%$ of their current events questions from traditional media. As Figure 3 shows, the number only dipped below 50\% in 2015, with the 2016 exam pointing toward a return to the 2009 balance. Although the representation of niche media channels increased, government sources were the ones that gained most ground. 


\section{Number of questions related to current events}

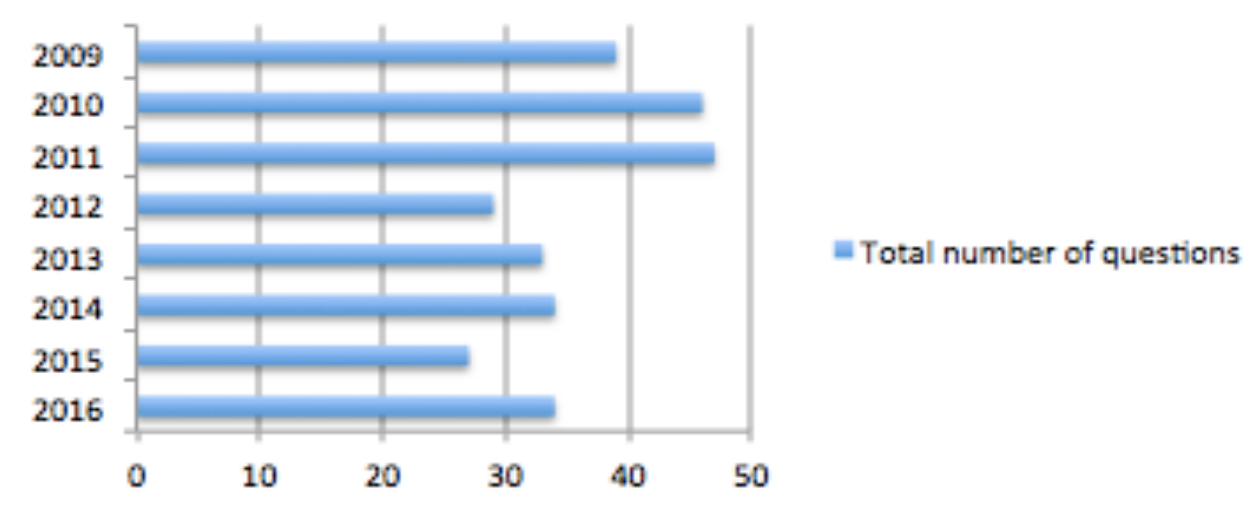

Figure 1

Number of Questions on Current Events by Year in ENEM

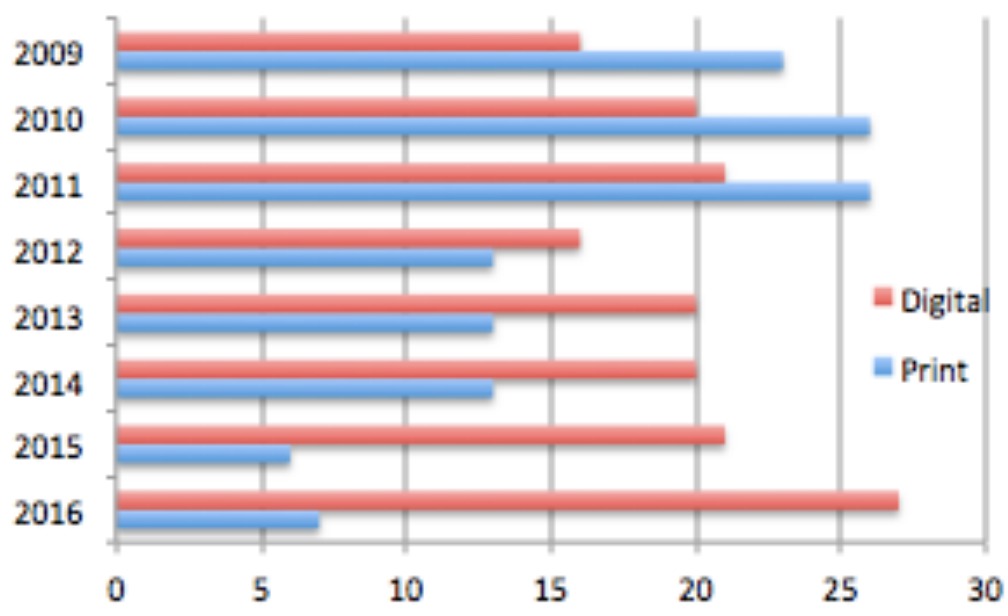

Figure 2

Number of Mentions of News Articles from Print and Digital Platforms in ENEM 


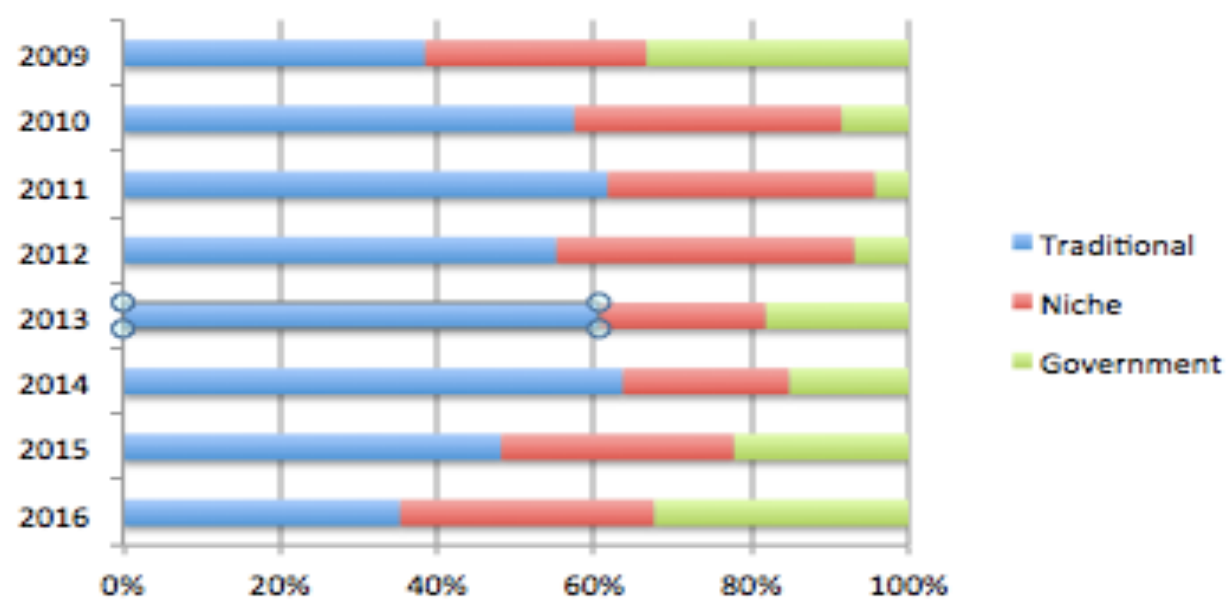

\section{Figure 3}

\section{Percentage of Questions that Mention Traditional, Niche and Government Sources}

As well as these quantitative comparisons, the questions can be analysed as qualitative data. This analysis reveals how the questions are formatted and the media content used within them: thus, of the form of media literacy required to achieve success in the ENEM exam.

In the majority of the questions, the media content has the status of an axiom, an unquestionable content that should be regarded as true with no room for interpretation. Students are asked what the article means, rather than asked to engage in critique of it. ENEM's multiple-choice question format then encourages a view that there is one correct interpretation of the text, and success in ENEM is achieved when students agree with the interpretation of the examiners. For example, take this translation of a question $^{3}$ from the 2010 exam, which is presented in full to give a sense of the style of ENEM.

\section{Excerpt 1 \\ Under the eyes of Twitter}

We live in the era of exposure and sharing. The line between public and private is starting to blur. The concept of privacy will change or disappear. The above sentences have exactly 140 characters. It is a short message that tries to convey a complex idea. Making such a synthesis is no small feat, but tens of millions of people practice it daily. Around the world, 2.4 trillion text messages are sent every month, all fitting only 140 characters, or a little bit more. It is also common to send e-mails, leave scraps on Orkut [a popular social network in Brazil in the early 2010s], talk to people on MSN Messenger, chat over the phone, receive messages anywhere and at anytime. We are all connected. Superconnected, actually, in many different ways.

\footnotetext{
${ }^{3}$ http://educacao.globo.com/provas/enem-2010/questoes/111.html (original Portuguese text)
} 
[...] The most recent example of people's demand for total connection and a new social syntax is Twitter, a new internet messaging service. Twitter can be understood as a combination of blog and phone. The messages are 140 characters long, just like SMS, but they circulate on the internet, like blog posts. Instead of being sent just to one person, like in your phone or in MSN Messenger, Twitter messages go to all "followers"-people who are following the sender. There can be 30, 300, 409 thousand followers.

--MARTINS, I.; LEAL, R. Época. 16 mar. 2009 (adapted fragment)

\section{Excerpt II}

\section{Tips to become a Better Twitter User}

- Put yourself in your reader's shoes: would you like to be informed that someone else is having a snack?

- Be careful with what you publish: do you really want everybody to know details of your love or sex life?

- Find an ideal messaging speed. If they are too few, no one will follow you; if they are too many, people will give up on following you.

- Use the search tool to find people and subjects that interest you. If you want to track the results of a particular search, subscribe to them using your $R S S$ reader.

- Enjoy in moderation: Twitter can make you unfocused. If you are concentrating on something, leave Twitter closed. Keep track of how much time you spend on it.

- If the conversation becomes too long, call the person or use the MSN Messenger.

- Don't try to read it all. It's impossible! Every now and then, reevaluate whether or not you want to follow all those people.

-- MARTINS, I.; LEAL, R. Época. 16 mar. 2009

Drawing a comparison between both excerpts, it is understood that Excerpt II is a stepby-step guide to influence the behavior of users, addressing the readers directly, while Excerpt I:

(A) Warns readers that the internet can become a problem because it exposes the lives of users and, therefore, it should be investigated.

(B) Teaches readers how they should proceed to understand, in-depth, the main communication tools of current times.

(C) Exemplifies and explains the fast new global messaging service that challenges communication habits and reinvents the concept of privacy.

(D) Attempts to clarify to readers how dangerous Twitter can be to work relationships, as well as on the personal sphere.

(E) Presents the results of a poll about the most used social networks and shows that Twitter is the favorite for most internet users. 
The excerpts criticize the superficiality of social media and reignite the slow media vs. fast media debate, but do so from the perspective of a print magazine. Phrases such as "Be careful with what you publish: do you really want everybody to know details of your love or sex life?"; "Enjoy in moderation: Twitter can make you unfocused" present more negative aspects of Twitter and do not mention the positive impact it could have.

ENEM examinees are not being encouraged to develop their own interpretation of the excerpts, nor to consider the wider context of publication. It could be argued that a print media outlet, which had been losing its audience to the internet, would present a more negative treatment of social media than a digital media source, which receives traffic from Facebook and Twitter (Hong, 2012). Such factors are disregarded by the question, which expects students to accept the discourse of traditional media at face value.

There are, however, some multiple-choice questions in the exam that seem to be compatible with media literacy education. Questions 125 and 126 from the 2010 exam, for example, require candidates to read a newspaper op-ed and reflect on the strategies used by the author to defend his opinion. Question 122 from 2011 and question 30 from 2013 present texts from different sources on the same subject and ask students to compare the two opinions. Although there is no reference to a political agenda behind the texts, which would be required in a more radical approach to media literacy education, these questions are consistent with Hobbs's (1997) suggestion that the media content should not only be presented, but also discussed and criticized.

Forty-nine of the 289 questions use quotes from government sources. They are included in a category of their own because they exemplify a significant trend in the content and structure of ENEM, suggesting the exam is oriented around functional rather than critical media literacy.

A telling example is question 28 from the 2014 exam, concerning the creation of the National Truth Commission (an investigation of violations of human rights during the 1964-1985 military dictatorship in Brazil). It reads:

The National Truth Commission (CNV) [from the acronym in Portuguese] brought together members of state commissions and several institutions to present summary of the work they had done and sign terms of cooperation with four organisations. The coordinator of CNV estimates that, up until now, the commission examined "at least" around 30 million pages of documents and interviewed hundreds of people.

Available in www.jb.com.br. Accessed in 2 March 2014 (adapted)

The news article above describes an initiative launched by the State as a result of the demands of several social movements in Brazil concerning events occurring between 1964 and 1988. The objective of this initiative is:

(A) Annul the amnesty conceded to military chiefs.

(B) Review the sentences given to political prisoners. 
(C) Pardon crimes committed by left-wing militants.

(D) Prove that society supported the anticommunist coup.

(E) Clarify the circumstances in which human rights violations happened.

This exemplifies the generally closed nature of ENEM's questioning. Students are asked about the objective of the initiative, and the right alternative (E) is the official government discourse about the matter, although some of the other answers arguably contain references to possible hidden agendas in the initiative, which had been pointed out by conservative media outlets. ${ }^{4}$ Thus, the choice of source and the format of the question (multiple-choice) both structure the discourse: success at this question requires students to validate the position of the government vis-à-vis a political debate that is ongoing in Brazil. A similar issue can be seen in question 19 of the 2012 exam, also about the Truth Commission.

The exam is also used as a platform for government campaigns. That was particularly notable in the 2009 exam, which had one question about the launch of a new government website and four questions about Ministry of Health campaigns. It can also be seen in question 137 of the 2014 exam, which make a reference to the water shortages in Brazil during that year. Despite not citing any government source or news article on the subject, the question requires students to calculate the amount of water a person can save by adopting certain measures recommended by the government. This approach to the water shortage issue puts the blame on the consumers and ignores reports that most of the water waste occurs during distribution $^{5}$, which is controlled by state-owned companies. Again, the student has no opportunity to criticize the official discourse and must endorse it in order to get a right answer.

The choices of which current events topics make it into the exam and which are left out seem to take the government's interests into account. In 2015 and 2016, no news event was more widely discussed in Brazil than the impeachment of president Dilma Rousseff (Almeida \& Silva Lima, 2016) ${ }^{6}$. However, there is no mention of the impeachment process in the exams from either year. Another particularly notable absence in the exam is the lack of reference to the protests against the government, which took millions of people to the streets of major Brazilian cities in 2013. The absence is even harder to justify after noting that the exam had questions about protests in Egypt and in the United Kingdom in previous years. If one of the premises of ENEM is that the questions that appear in the exam should be relevant to students' daily lives, it is difficult to explain why major protests against the government in Africa and Europe are more relevant to a Brazilian student than the protests happening in their own country during that year.

One last observation about the questions concerning the government in ENEM involves the writing tasks. They are the only non-multiple choice part of the exam,

\footnotetext{
${ }^{4} \mathrm{http} / / / \mathrm{www} 1$. folha.uol.com.br/fsp/opiniao/32697-o-risco-de-uma-comissao-do-acerto-de-contas.shtml

${ }^{5} \mathrm{http} / / / \mathrm{www} 12$.senado.leg.br/noticias/materias/2015/01/23/brasil-desperdica-quase-40-de-sua-aguatratada-em-rede-de-distribuicao-falha

${ }^{6} \mathrm{http} / / /$ portal.comunique-se.com.br/impeachment-de-dilma-foi-o-fato-mais-marcante-de-2016-avaliamjornalistas/
} 
and, therefore, the only one in which students have the chance to express their own ideas freely. However, four out of the six writing tasks analysed by the study required the student to write about the government or its projects. In 2012, 2013, 2014, 2015 and 2016, students are implicitly asked to support the government's stance on topics such as immigration policy, changes to the DUI law, and restrictions to advertisements for children. In 2009, the writing task was built around deconstructing the idea that all politicians are corrupt. By inviting the students to write about themes in which the government has a clear agenda, in an exam that is elaborated and assessed by a government institution, these tasks discourage the adoption of a critical stance against the hegemonic discourse of the government.

In summary, these factors limited the extent to which the media literacy evident in ENEM can be said to be critical:

- the preponderance of traditional media and government sources;

- the way source texts are presented as axiomatic statements rather than as opinions open to critique;

- the use of multiple-choice questions for the most part; and

- the avoidance of positions critical of the government

Students are being asked to read the news, but not to formulate their own opinions on the topics discussed; rather, success in ENEM comes from being able to identify the nature of opinions that have been selected, interpreted and defined by the examiners.

\section{Interview Results}

When Brazilian teachers were asked about how they would define the criteria used by INEP to choose which current events are featured in ENEM questions every year, the majority of teachers mentioned that the choice was based on the "relevance" of facts, as well as the frequency and intensity with which they were reported in media outlets throughout the year.

While most teachers did not go beyond that description, some expressed opinions in favor or against the criteria. One of the interviewees (English teacher, 25 years of experience) stated that "ENEM uses criteria that in my opinion are fair, presenting relevant themes and problems and demanding students to appropriate those problems, interpret them and propose coherent and pertinent interventions." This should apply particularly to the writing tasks, which often ask students to take a stance and make a proposal based on excerpts from media articles about a contemporary problem, according to the interviewee.

Other teachers were more critical of the criteria, pointing out their vagueness, as well as regional and political bias. Some comments include these exemples:

I do not know the criteria used by the Ministry of Education to choose which current events are featured in the questions. There is a directive of the ministry, which reaches us at the schools, saying that themes that are relevant to the students' daily life will always be part of ENEM. The question remains: what 
does the ministry consider to be relevant to daily life? (Geography, 8 years of experience)

They certainly keep an eye on questions that are in the agenda of political discussions, which depends on the media and government organs. I do not believe that what is discussed in social movements, for instance, is taken into consideration with the same emphasis. (History, 13 years of experience)

Given that ENEM is used to 'catechise' students in a perspective that aims at standardisation, responding to certain interests, I believe that the criteria used are shallow, to say the least, and do not do what they were expected to do. (History, 10 years of experience)

[The criteria] are supposed to reflect the reality of the entire country, but currently emphasise the Southeast region. (History, 5 years of experience)

The last excerpt corroborates a finding of the content analysis: by prioritising content from traditional media sources which are all based in São Paulo and Rio de Janeiro, in the Southeast region of Brazil, ENEM questions echo a regional and metropolitan bias that is seen in the media. There is an emphasis on news from the richest southern regions of the country, as opposed to the North and the Northeast. This defeats the purpose of creating an exam which uses current events as a way to contextualise content and bring it closer to the students' daily lives. A water shortage in the Southeast, for instance, is an important issue for a student in São Paulo, but hardly concerns the daily lives of students from Roraima (in the North of Brazil), who might be better informed about the floods in their region. The issues faced by the Southeast student were featured in ENEM, while issues faced by the student from the North were ignored.

When asked about the media consumption habits of students, all 11 respondents mentioned that their students use social networks and instant messaging as their main source of news, providing links to news websites. Television and print magazines were a distant second, with not a single mention of print newspapers. All teachers but one also agreed that it is possible, nowadays, to fully prepare for an exam like ENEM using only digital media, without resorting to print or television. One teacher mentioned that he encouraged the use of smartphones by students for that purpose.

I say that they should immerse themselves in information, no matter what platform it comes from. I stimulate the directed use of smartphones, a device that is inseparable from them, as something that can help them in the exam. After all, you should approach the student's reality, not distance yourself from it. (Geography, 8 years of experience).

Other teachers pointed out that most of the content from print media sources are currently available online. This was also observed in the content analysis: due to the 
large number of mentions to digital versions of newspapers and magazines, traditional media remains a dominant source in ENEM questions in spite of the decline of print.

Nowadays almost everything that is printed can be found on the internet. A big part of the content that is accessed on the internet is produced by the same media companies that own print newspapers and magazines (History, 13 years of experience).

The use of digital media was also mentioned as a way of succeeding despite the regional bias. For exemple, one teacher commented:

There are students who live in rural areas and do not have easy access to print media, but still succeed in ENEM. (English, 25 years of experience).

A majority of the interviewees observed students' lack of critical reading skills. They show symptoms of information obesity (Whitworth, 2009), and their reliance on social media for news makes them vulnerable to the filter bubble (Pariser, 2011). Teachers said:

They do not check sources. I always insist on this point. [I tell them] they should look for other sources to check the veracity of any given information, taking into account that there is always manipulation on the internet and we should look for the facts before sharing something. (Geography, 8 years of experience)

They lack critical thinking and the information they have is very superficial. (History, 32 years of experience)

They are often confused by humorous fake news sites and have a hard time telling what is true from what is a joke. (History, 5 years of experience)

They believe what they read on the news without questioning it. (Geography, 33 years of experience)

Interviewees also believe that students engage with the news not out of personal interest, but in order to score well in ENEM. This suggests that the exam can determine not only what is taught in classrooms, but also the reading habits of students themselves:

Due to the necessity of taking part in ENEM, students are obliged to consume news. (Mathematics, 34 years of experience)

The need of approval in ENEM leads students to read the news. (English, 25 years of experience) 
The huge majority of students only seek information due to pressure from their parents or because they believe it is needed for the entrance exams, which reflects a utilitarian view of journalism. (Journalism, 8 years of experience)

These data add weight to the observation that the structure and content of ENEM exams promote a "utilitarian" or functional view of media literacy, rather than a critical engagement with how these news stories are relevant to learners' everyday lives. However, it should also be observed that the teachers are reporting on their students' habits at second hand; more direct research with high school students as the subjects would be needed to establish how well the teachers' perceptions matched the reality.

In the interviews, teachers were presented with five topics and asked to rank them according to their perception of how likely each was to appear in the exam. When asked whether ENEM had any influence in how much time they dedicated to certain subjects at their classes, there was an almost even split: for five teachers, a higher perceived likelihood of a topic being discussed in an ENEM question led to a higher amount of time dedicated to that subject - and vice-versa. For six, however, there was no correlation, and topics such as the World Cup 2014 protests and the protests against the government would be among their priorities in terms of classroom time, despite the fact that they believed them unlikely to appear in the exam.

In their answers, some teachers justify the decision of the Ministry of Education not to include in ENEM questions about widely covered events that could be sensitive to the government.

A question like this [about the accusations of corruption in Brazil's state-owned oil company] would never be asked. You should not forget that ENEM is a federal exam and they would not rub salt in that wound. (History, 30 years of experience)

For some of those themes, there's not a lot of consensus about their meanings and effects, which opens room for more confusion than other, simpler questions that could be 'verifiable' as right or wrong. (Journalism, 8 years of experience)

Five of the eleven teachers interviewed believed that the protests against the government were very likely to be mentioned in ENEM questions. This view is directly contradicted by the content analysis, which shows that ENEM ignored the protests ever since they became widespread in 2013 and has not asked a single question about accusations of government corruption since 2009 (the earliest year analysed in this study). On the one hand, these teachers' answers show a lack of knowledge about the criteria used by ENEM for current events questions. On the other hand, it is a sign that these teachers are not too concerned with "teaching to the exam" and teach their current events classes according to their own judgement of what is relevant, instead of checking the history of publicly available ENEM questions to assess whether or not a theme is likely to be discussed. 
When asked about what criteria they use to decide which news subjects they will discuss and for how long, three teachers attributed the choice to the media or to a thirdparty company that provided educational textbooks.

The choice is made by the press when a subject receives a strong coverage. (Geography, 33 years of experience)

In general, the current events classes follow what we could call 'hard news' - hot topics and events which come up and have big repercussions. (Journalism, 8 years of experience)

Since I have always worked in private schools, we are obliged to follow the content selected by a publisher that is hired to make textbooks, therefore the themes covered vary greatly from year to year, and the time attributed to each lesson is regulated to fulfill the need to cover all the content (after all, the parents pay for the textbook and you should cover every single chapter of it, even if it means that some subjects will receive a superficial treatment). (History, 10 years of experience)

Such answers, particularly the last, are troublesome in terms of media literacy education: if the teacher has no freedom to choose the themes for their class according to their own critical judgement, they cannot be expected to encourage their students to develop critical thinking skills.

Finally, teachers were asked to suggest changes to the current format of ENEM. Again, a common theme was the issue of regional bias. Four teachers suggested that the exam should include questions from more regions of the country or offer different sets of questions for each region, to approach the reality of the student. Another suggested the extinction of ENEM, despite recognising that it is "compatible with the terrible educational system that we have" and that it "discusses current events in a "possible" way, given the awful political education that is offered to students, which leaves them unable to understand the world in which they live" (History, 13 years of experience).

\section{CONCLUSION}

Though ENEM does achieve the goal of exposing students to media, the analysis of the exam's content and format, and of the qualitative data drawn from the interviews, suggests that the students are expected to engage with media literacy at only a functional level. In contrast to the views of Hobbs, mentioned earlier, students are not being encouraged to engage with the media on their own terms, being asked to select information from multiple sources, analyse and evaluate this information and create their own interpretation (Hobbs, 2005). Even Hobbs' basic, implicit political agenda for media literacy, of "teaching students to question textual authority and to use reasoning to reach autonomous decisions" (Hobbs, 1998, p. 22), is difficult to discern in ENEM due to its heavy use of multiple-choice questions and presentation of extracts as axiomatic and/or factual statements rather than as texts for analysis and critique. 
Success in these media-related elements of ENEM, for students and for the schools that teach to the exam, is achieved by acquiring an ability to identify what the examiners will have decided is the right interpretation of a media text, as opposed to students' developing their own interpretation.

Although it should be noted that a significant portion of the interviewees claimed not to be influenced by the exam when teaching their students about current events, the growing emphasis placed on ENEM school rankings could increase the pressure for them to teach to the exam.

The findings in both the content analysis and the interviews suggest that, while the government's initiative to include current events and their discussion in the curriculum is a step in the direction of promoting media literacy education, doing so through a centralised, standardised exam is contradictory and poses challenges that are hard to overcome. The pro-government agenda seen in ENEM is an example of the sort of biases that emerge from such a system. The idea of centralising the power in a media literacy education initiative might make sense from an organisational standpoint, but misses the point that media literacy requires a certain degree of decentralisation, as noted by both Hamelink (1976) and Freire (1970).

Taking those findings into consideration, it can be concluded that the media literacy curriculum shaped around ENEM does not fulfil the Ministry of Education's declared goal of preparing students to think autonomously and teaching content that is relevant to daily life. A course about current events focused on preparing students for ENEM would require them to study the issues of the Southeast region of the country (regardless of their own region), trust traditional media sources and ignore news that might embarrass the government or contradict official discourse. A school with such criteria would hardly be teaching media literacy, but would perform well in the ENEM rankings.

The interviews show that media literacy education is a necessity. Teachers claim that their students consume a lot of information but reflect very little about it, have a limited interest in the news and find it difficult to analyse the media critically, often falling prey to hoaxes and fake news. But it is improbable that those issues will be solved by changes in the national curriculum standard or an institutionalised approach to media literacy education. The experience of ENEM shows that a government-led education initiative is not very likely to teach students to be critical of the government and to analyse and evaluate its official discourse instead of taking it at face value.

A regional, decentralized media literacy education effort would be more likely to accomplish ENEM's promise of preparing students for daily life and making sure what they learn is relevant to their context. In its current form, considering what was observed in this study, the centralised and institutional nature of ENEM make it work against what were supposedly its initial goals. 


\section{REFERENCES}

Almeida, A.T.S. \& Silva Lima, V.T. (2016). Dilma Rousseff na imprensa brasileira: Da reeleição ao processo de impeachment. Revista Encontros 14(26), 102-113.

de Carvalho Andrade, E. (2011). Rankings em educação: tipos, problemas, informações e mudanças. Estudos Econômicos (São Paulo), 41(2), 323-343.

Auxiliadora, M., \& Santos Schmidt, M. (2015). Formação da consciência histórica ou desenvolvimento de competências? Considerações sobre o ensino de história para jovens brasileiros. Diálogos - Revista Do Departamento de História E Do Programa de Pós-Graduação Em História, 19(1), 87-116.

Cakmak, Ebubekir EC and Tuzel, Sait ST (2015) Debates about the future of media literacy in Turkey, Journal of Media Literacy Education, 7(3), 1 -12.

Freire, P. (1970). Pedagogy of the oppressed. Harmondsworth: Penguin.

Hamelink, C. (1976). An Alternative to News. Journal of Communication 26(Autumn), 120-123.

Hipólito, A. and Silveira, H. (2011). As questões de Química do Exame Nacional do Ensino Médio (ENEM) em um enfoque transversal e interdisciplinar. Encontro Nacional de Pesquisa em Educação e Ciências, VIII.

Hobbs, R, (1997) Expanding the concept of literacy in R. Kubey (Ed), Media literacy in the information age (pp. 163-183). New York: Transaction Press.

Hobbs, R. (1998). The seven great debates in the media literacy movement. Journal of Communication, 48(1), 16-32.

Hobbs, R. (2005). The state of media literacy education. Journal of Communication, 55(4), 865-871.

Hobbs, R., \& Frost, R. (2003). Measuring the acquisition of media-literacy skills. Reading Research Quarterly, 38(3), 330-355.

Hong, S. (2012). Online news on Twitter: Newspapers' social media adoption and their online readership. Information Economics and Policy, 24(1), 69-74.

INEP - Ministério da Educação, Instituto Nacional de Estudos e Pesquisas Educacionais (2000). Documento Básico. Brasília.

INEP - Ministério da Educação, Instituto Nacional de Estudos e Pesquisas Educacionais - (2007). Revista do ENEM. Brasília.

Livingstone, S. (2008) Engaging with media - a matter of literacy? Communication, Culture \& Critique, 1 (1). 51-62.

Lopes, A. C., \& López, S. B. (2010). A performatividade nas políticas de currículo: o caso do ENEM. Educação Em Revista, 26(1), pp. 89-110.

Nam, S. (2010). Critical media literacy as curricular praxis. Javnost - The Public, 17(4), pp. 5-23.

Pariser, E. (2011). The filter bubble: What the Internet is hiding from you. Penguin UK.

Santos, J. M. C. T. (2011). Exame Nacional do Ensino Médio: entre a regulação da qualidade do Ensino Médio e o vestibular. Educar Em Revista, abril/junho(40), 195-205. 
D. Venticinque \& A. Whitworth | Journal of Media Literacy Education 2018 10(3), 95 - 112

Travitzki, R., Calero, J., \& Boto, C. (2014). ¿Qué información proporciona el Examen Nacional de Enseñanza Media (ENEM) a la sociedad brasileña? Revista Cepal, Agosto (113), 163-181.

Whitworth, A. (2009). Information obesity. Elsevier.

Whitworth, A. (2014). Radical information literacy: Reclaiming the political heart of the IL movement. Oxford: Chandos. 